\title{
Historical Materialism and the National Development Question in Nigeria
}

\author{
Kingdom E. Orji, Phd \\ Department of History and Diplomatic Studies \\ Faculty of Humanities, Ignatius Ajuru University of Education \\ Rumuolumeni, Port-Harcourt
}

\section{Doi:10.5901/mjss.2013.v4n3p195}

\section{Abstract}

Since the amalgamation of 1914 that culminated in what later came to be known as Nigeria, the question of national development has engaged the attention of scholars. There is every indication that the national development project has witnessed slow socio-economic hiccups to the dismay of analysts. The major obstacle to viable economic advancement in the Nigerian polity has been located in historical materialism which deals with 'that view of the course of history, which seeks the ultimate and great moving power of all important historic events in the changes in the modes of production and exchange in the consequent division of society into distinct classes and in the struggles of these classes against one another'. It identifies the primacy of material conditions in the analysis of society, where the essence of democratic governance is propelled by a penchant for primitive accumulation of wealth, there will be little or no prospect for natural development. A comparative analysis unveils the fact that National Development Plans which have produced in-depth socio-economic transformations in Soviet Russia and China in the 20th century have left much to be desired in Nigeria. The obvious reasons with attendant consequences include ethno-religious crises, sectoral violence, electoral fraud, official corruption, militancy, environmental degradation, political instability and inter-alia. This paper posits that sustainable solution that thrives on focused transparent leadership, accountability and rule of law could be efficacious.

\section{Introduction}

It is a common knowledge that no nation can afford to remain static in a dynamic world hence the unbridled quest for economic advancement. In the comity of Nations, the drive for development has sometime occasioned the adoption of crude ideologies to justify questionable approaches. During the early $15^{\text {th }}$ and $16^{\text {th }}$ centuries, the Portuguese and the Spanish embarked on 'Old Imperialism' and this informed the evolution of the Trans-Atlantic Slave Trade. The discovery of the New World equally impacted negatively on the process as for more than three centuries, Africans were horded into the baracoons for shipment to the Americans under heinous conditions. The protagonists of the new wave of imperialism championed by the British, French, Germans and their cohorts sought justification for their nefarious proclivity in Darwin's theory of' Natural Selection and the Survival of the Fittest' by which they prayed that stronger nations must 'rule' the weak ones. This trend laid the foundation for colonial hegemony and the superimposition of foreign domination. Lenins claim that imperialism is the highest stage of Capitalism is rooted in historical materialism.

It must be stated unequivocally, that colonialism left many indigenous economies disarticulated

(Ake, 1981). This submission is critical in the assessment of the national development project. This paper intends to clarify some of the relevant concepts that have direct bearing on our subject matter in relation to an evaluation of the state of the Nigerian economy. Similarly, the centrifugal force that impact negatively on the development process will equally be examined and a possible solution proffered.

\section{Clarification of Concepts}

Any meaningful discourse on national development must adumbrate on two key concepts: the nation and development. While analyzing the nation-building process, Elaigwu (2011) conceives of a nation as it applies to three levels of human groups which may refer to

(i) a suitable, historically developed community of people with a territory, economic life, distinctive culture and language in common

(ii) the people of a territory united under a single government, country or state

(iii) A people or a tribe 
He goes further to define a nation-state as the highest point in the process of state building. Thus in Western experience, the nation was established before the state and the nation-state forms the end product of those processes. In his submission, Axtman (2004) outlines the historical constitution of a nation-state to comprise the following (i) the territorial state and the unitary sovereign will (ii) the territorial state as a homogenous nation-state (iii) democratization and popular sovereignty and (iv) the global spread of the idea of nation-state. It may not be absurd to assert that Nigeria is in the process of transforming to a nation-state.

Generally, the term 'development' implies material progress that should be holistic in nature. Polities are at one level of development or the other. Adeyomo (2003) views development at two extremes viz individual development which implies increased skill and capacity, greater freedom, creativity, self-discipline, responsibility and material well being and the social group development which is synonymous with an increasing capacity to regulate both external and internal relationship. He further reasons that the realization of development goals must go beyond the economic and the physical to impact on the individual and collective well being and 'no country can be regarded as fully developed if it cannot provide all its people with such basic needs as housing, clothing, food and minimal education.

There is a clear-cut difference between growth and development even though some scholars unwittingly and erroneously use these interchangeably. Kindleberger (cited in Yusuf 1996: 30) states that:

"Growth may well imply not only more output, but also more inputs and more efficiency i.e. an increase in output per unit of input. Development goes beyond these to imply changes in the structure of outputs and in the allocation of inputs by sectors. By analogy with the human being, to stress growth involves focusing on height or weight, while to emphasize development draws attention to the change in functional capacity - in physical co-ordination, for example or learning capacity".

Cognizance must be taken of sustainable development which emphasizes that the process of socio-economic development should not endanger the fate of future generations through environmental degradation (Arokoyu, 2004, Oyeshola, 2008).

Historical materialism is an integral part of the political economy approach in the study of society. It emphasizes the primacy of matter in analyzing causation in a historical process. Collingwood (1946) posits that history is a scientific inquiry into past human actions through the interpretation of evidence for the purpose of human self knowledge and development. In the words of Essoh (2005:69) historical materialism is:

that view of the course of history which seeks the ultimate cause of the great moving power of all important historic events in the changes in the modes of production and exchange, in the consequent division of society into distinct classes and in the struggles of these classes against one another.

It has been observed that Karl Marx's clearest formulation of his 'materialist conception of history' was in the 1859 preface to his book ' A Contribution to the Critique of Political Economy' where he states that by the social production of their existence, men inevitably enter into definite relation of production in their development of material forces of production. The mode of production of material life conditions the general process of social, political and intellectual life...the changes in economic foundation lead sooner or later to the transformation of the whole immersive superstructure' (Wikipedia). Ekekwe (1984) posits that the pursuit of national development might turn to a mirage because the bourgeoisie in the periphery uses the state to enhance its own accumulation, perhaps at some expense to the international bourgeoisie.

This phenomenon leads to inequality in society, that society cannot have political democracy (which translates to national development) because political power will tend to polarize around economic power. Also a society where a high degree of economic inequality exists must necessarily be repressive. This repression arises from the need to curb the inevitable demand of the have-not far redistribution. We see here economic conditions not only setting the tone of politics but also defining the role of coercion in society. We now subject the state of the Nigerian economy to the crucibles of critical analysis.

\section{The State of the Nigerian Economy and Obstacles to National Development}

Currently the Nigerian State is grappling with a myriad of socio-political, economic and ethno-religious crises that have the capacity to leave the economy in a sordid state. The 2006 population census reveals that Nigerian's population is more than $141,000,000$ million persons with about $70 \%$ reeling in squalor. Soludo (2012: 13) observes that 
with over $\$ 600$ billion from oil, Nigeria has not been able to provide any of the Maslow's basic needs - food, shelter, water, electricity, health care, education etc. even something as basic as identifiable street address is difficult. The basic infrastructures Nigeria inherited from the colonial masters at independence especially the urban water schemes, electricity, railways, postal services and urban waste disposal have all but disappeared. Nigeria's per capita income of about $\$ 1,180$ as of 2011 is in real terms much lower than the estimated $\$ 1,000$ in 1965, and still lower than $\$ 2,300$ of 1980. Life expectancy was 54 in 1970 but 48 years in 2010, poverty level was $45 \%$ in 1970 but $69 \%$ in 2010 (and estimated $71.5 \%$ in 2011), unemployment was $15 \%$ in 1970 but about $24 \%$ in 2010.

Table: Analysis of poverty profile in Nigeria, $1996-2010$.

\begin{tabular}{|l|c|c|c|c|c|}
\hline \multicolumn{1}{|c|}{ States } & $\mathbf{1 9 9 6}$ & $\mathbf{2 0 0 4}$ & $\mathbf{2 0 1 0}$ & $\mathbf{2 0 1 0 - 2 0 0 4}$ & $\begin{array}{c}\text { \% Changes in 2010 } \\
\text { Compared to 2004 }\end{array}$ \\
\hline Abia & 56.2 & 22.27 & 63.4 & 41.13 & 184.69 \\
\hline Adamawa & 65.5 & 71.74 & 80.7 & 8.96 & 12.49 \\
\hline Akwa-lbom & 66.9 & 34.82 & 62.8 & 27.98 & 80.36 \\
\hline Anambra & 51 & 20.11 & 68 & 47.89 & 238.14 \\
\hline Bauchi & 83.5 & 86.29 & 83.7 & -2.59 & -3.00 \\
\hline Bayelsa & 44.3 & 19.98 & 57.9 & 37.92 & 189.79 \\
\hline Benue & 64.2 & 55.33 & 74.1 & 18.09 & 43.48 \\
\hline Borno & 66.9 & 53.63 & 61.1 & 7.47 & 13.93 \\
\hline Cross-River & 66.9 & 41.61 & 59.7 & 18.09 & 43.48 \\
\hline Delta & 56.1 & 45.35 & 70.1 & 24.75 & 54.58 \\
\hline Ebonyi & 51 & 43.33 & 80.4 & 37.07 & 85.55 \\
\hline Edo & 56.1 & 33.09 & 72.5 & 39.41 & 119.10 \\
\hline Ekiti & 71.6 & 42.27 & 59.1 & 16.83 & 39.82 \\
\hline Enugu & 51 & 31.12 & 72.1 & 40.98 & 131.68 \\
\hline Gombe & 83.5 & 77.01 & 79.8 & 2.79 & 3.62 \\
\hline Imo & 56.2 & 27.39 & 57.3 & 29.91 & 109.20 \\
\hline Jigawa & 71 & 95.07 & 79 & -16.07 & -16.90 \\
\hline Kaduna & 67.7 & 50.24 & 73 & 22.76 & 45.30 \\
\hline Kano & 71 & 61.29 & 72.3 & 11.01 & 17.96 \\
\hline Katsina & 77.7 & 71.06 & 82 & 10.94 & 13.40 \\
\hline Kebbi & 83.6 & 89.65 & 80.5 & -9.15 & -10.21 \\
\hline Kogi & 75.5 & 88.55 & 73.5 & 15.05 & -17.00 \\
\hline Kwara & 75.5 & 85.22 & 74.3 & -10.92 & -12.81 \\
\hline Lagos & 53 & 63.58 & 59.2 & 4.38 & -6.89 \\
\hline Nasarawa & 62.7 & 61.59 & 71.7 & 10.11 & 16.42 \\
\hline Niger & 52.2 & 63.9 & 43.6 & -20.3 & -31.77 \\
\hline Ogun & 69.9 & 31.73 & 69 & 37.27 & 117.46 \\
\hline Ondo & 71.6 & 42.14 & 57 & 14.86 & 35.26 \\
\hline Osun & 58.7 & 32.35 & 47.5 & 15.15 & 46.83 \\
\hline Oyo & 58.7 & 24.08 & 60.7 & 36.62 & 152.08 \\
\hline Plateau & 62.7 & 60.37 & 79.7 & 19.33 & 32.02 \\
\hline Rivers & 44.3 & 29.09 & 58.6 & 29.51 & 101.44 \\
\hline Sokoto & 83.9 & 76.81 & 86.4 & 9.59 & 12.49 \\
\hline Taraba & 65.5 & 62.15 & 76.3 & 14.15 & 22.77 \\
\hline Yobe & 66.9 & 83.25 & 79.6 & -3.65 & 4.38 \\
\hline Zamfara & 83.9 & 80.93 & 80.2 & -0.73 & -0.90 \\
\hline Fct & 53 & 43.32 & 59.9 & 16.58 & 18.27 \\
\hline All Nigeria & 65.6 & 54.4 & 69 & 14.6 & 26.84 \\
\hline Nenal| & & \\
\hline
\end{tabular}

Notes (i) Negative numbers depict deelire in poverty incidence. Thus, poverty incidence dedre in only 9 state and increased in 32 states in 2010.

Source: Cited in Soludo, C.C (2011) Nigeria towards the creation of Incentives and structures for Good Governance P.39. 
It is in the light of this abysmal performance that the world Bank in February 2007 branded the toga of 'failed' or 'fragile' states on Nigeria and other 50 countries like Sao Tome, Papua Nar Guinea, Djoubti and Uzbekistan because they (i.e. failed states) "Lack the will and capacity to engage productively with their own citizens so as to ensure security of life and property, safeguard of human rights, provide basically minimum institution and infrastructure for development, confront development challenges of weak governance, administrative capacity, chronic humanitarian crises, persistent or endemic social tensions ,violence, threats of institutional breakdown and civil war"( Oyovbaire, 2007).

Some of the challenges militating against the national development project in Nigeria include the following, the consequences of the colonial heritage. Undiyaundeye (2011) notes that the problems of nation-building that were to be the bane of Nigerian nation-state began with the amalgamation of 1914. It is obvious that the amalgamation was suggestive of the hording together of strange bed fellows leading to the endemic crisis of what Toyo (2012) has described as the problem of exclusion and a sense of alienation. In principle, Nigeria is one indivisible organic whole but in practice there are visible differences that are derailing. Egwemi (2012) observes that the colonial legacy in the form of the 1914 amalgamation is responsible for the absence of unifying fibers that could make for national integration. It is no gainsaying that colonialism to a large extent, laid the foundation for underdevelopment in Nigeria. For one, the fact that the colonial economy existed in the interest of metro pole Britain meant that its operations were tailored to siphon the wealth of the 'subject' people. This was the raison d'être for the exploitation and haulage of the cash crops like groundnut in the North, the cocoa in the West and palm produce in the East at the detriment of the peasantry. More so, the introduction of taxation spelt doom for the workforce as a good percentage of vivile men and women sought wage labour in a bid to earn pound sterling to pay tax thereby plucking them out of their indigenous economic roots like farming and fishing and local manufacture. Concomitantly, colonial education was bereft of the principle and practice of self-reliance. The effort of colonial education in the area of technical education left much to be desired as the main interest was the production of clerical manpower.

There seems to be a nexus between the ravages of the colonial economy and the corruption epidemic in Nigeria today. At independence, the political class charged with administrative engineering was not grounded in the art of good governance. They perceived politics as public ardor for private enrichment. There is little wonder that corruption was identified as one of the major excuses for military putsch in January 1966. While proffering justification for the January 1966 coup, Nzeogwu amongst others, noted

\begin{abstract}
Our enemies are the political profiteers, swindlers, the men in the high and low places that seek bribes and demand ten percent, those that seek to keep the country divided permanently so that they can remain in office as ministers and VIPs of waste, the tribalists, the nepotists, those that make the country look big for nothing before international circles, those that have corrupted our society and put the Nigerian political calendar back by their words and deeds (Obasanjo 1987:99)
\end{abstract}

Corruption has produced a chain reaction that has impacted negatively on Nigeria's first post-independence government led by Prime minister Tafawa organized general and regional elections in 1964 and 1965. The polls returned the government to a second term office but were characterized by widespread complaints of fraud, violence and intimidation. Protest in the wake of the regional elections, which in some areas had degenerated into a violent exercise in competitive rigging, led to widespread violence and inter-communal rioting that claimed more than 200 lives.

One critical element of corruption is the proclivity towards primitive accumulation which is an offshoot of historical materialism. It is obvious that more than $70 \%$ of Nigerians live below poverty line and this implies that this endangered class earns less than $\$ 1$ per day. What is intriguing is not the scourge of poverty but the dismal performance of official response to deal with this menace as a result of fraudulent practices. While x-raying the challenges faced by poverty reduction programmes in Nigeria, Radda (2008) posits that Nigeria is under siege by a rapacious oligarchy and its international collaborators. Hence, the nation's resources are in the hands of an illegitimate and illegal political class that have weakened national structures in conjunction with corrupt government officials; the overwhelming majority of these politicians who are motivated by avarice and pecuniary reasons usurp and foist themselves on the electorates .

As a fallout of the foregoing, Nigeria after independence at a point produced a leadership class that was illequipped to formulate and implement development objectives.

\title{
The Challenge of Neglecting Development Plans
}

National development is a conscious effort by any well-meaning political administration to anchor its citizens on the part of material progress and sustainable welfare and must not be haphazardly pursued. It was this concept that informed the 
adoption of calibrated development plans first by some socialist economies, Salawu, Muhammed, Adekeye \& Onimajesin (2006) observe that theoretically, development plans of any sort involve deliberate efforts on the part of government to speed up the process of social and economic development of a country National development plans were first introduced by Josef Stalin in his attempt to reshape the economic physiognomy of the Soviet Union with a focus on the material well being of the citizenry, industrialization and the realization of economic parity among the nations with the first Five Years Plan lunched in 1928 (Ralph, Lerner, Meacham, Wood, Hull and Burns, 1997). It is worthy of note that Stalin's Five Year Plans were aimed at strengthening and enriching the country, laying a ground work for a true worker's society and overcoming the Russian reputation for backwardness and the successful implementation of these economic plans shielded the Soviet Union from the adverse effects of the Great Depression of the late 1920s. Stalin's development plans later became model for most Third World countries, like China under the Communist regime of Chairman Mao Tse-tuing.

In Nigeria, Yusufu (1996)traces the origin of national development plans to the colonial era when he notes that the first ever development plan which had as a specific objective the welfare of the citizens and tagged A Ten-year Plan of Development and Welfare for Nigeria to span 1946- 1956. At independence, Salawu, Muhammed Adekeye and Onimajesin (2006) posit that Nigeria has launched four different development plans namely the First National Development Plan of 1962- 1968 which recorded some significant achievements such as the establishment of the PortHacourt oil refinery, the Niger bridge, the first generation universities viz University of Ibadan, University of Lagos, the Ahmadu Bello University by the Northern Region, the University of Ife by the Western region and the University of Nigeria Nsukka by the Eastern Region respectively. The second national development plan was launched by General Yakubu Gowon from 1970 - 1975 witnessed some remarkable achievements like the introduction of the National Youth Service Scheme (NYSC), the construction of many federal roads, the introduction of Federal Scholarship and Loan Scheme for Nigerian Students. The third National Development Plan was also embarked upon by Gowon though it was truncated by the military coup of General Murtala Mohammed. Alhaji Sheghu Shagari crafted the fourth National Development Plan of 1981 - 1985 with the intention of establishing a solid base for the long-term economic and social development of Nigeria but this plan was terminated by the 1983 coup d'état of the duo of General Muhammed Buhari and Major General Tunde Idiagbon.

Salawu, et al (2006) observe that the traditional national development plans were jettisoned by the General Babangida Junta in favour of rolling plans under the Structural Adjustment Programmes (S.A.P) and later abandoned by the military dictatorship of General Sani Abacha who launched the Vision 2010 on September 18, 1996, and thus began a gradual but abysmal shift with bleak implications for the Nigerian economy. Mohammed (2011) notes that "contrary to the claim of apologists that SAP brought rational conduct, efficiency and competition among economic agents, the programme led to the collapse of living standard of majority of Nigerians, devaluation and hardship. It further nurtured state repression and authoritarianism as evidenced in the closure of media houses ban on association, and unions, arbitrary arrest, torture, extra-judicial killings, etc".

The abandonmnent of national development plan has unleashed untold hardship on the economy. The major excuse could be located in the operation of historical materialism which stimulates primitive accumulation and rapacious inclinations. Against this backdrop, Salawu, Muhammed, Adekeye and Onimajesin (2006) note that "what the nation has inherited in the absence of well articulated development plans are budget frauds, road contract scandal, oil scams and unchallenged or unchecked high level of financial corruption at all levels of government in Nigeria". The overall implication is that the economy is prostrate with attendant consequence of high of incidence of poverty, unemployment youth restiveness, military ethno- religious crises, electoral fraud, the national question, insecurity of lives and property, interalia. But a wary researcher would want to know the aupwer to the national development riddle charting as we chart the way forward.

\section{The Way Forward}

From the forgoing, it is self evident that Nigeria's quest for national development may remain a wild goose chase and a mirage if drastic measures are not taken. There is the need for a comparative analysis along development models. Even the New Partnership for Africa's Development (NEPAD) recognizes this in one of its avowed objectives in the firm belief that no nation is an island. In recent times, some countries under the auspices of the Association of South East Asian Nations (ASEAN) have made significant economic breakthrough in the field of industrialization and capacity building. Ugo (2010) observes that the objectives of ASEAN include the acceleration of economic growth, social progress, and cultural development amongst its member nation building. The study further reveals that ASEAN, a geo-political and economic conglomerate of ten South East Asian polities draws strength from a development model that attaches high premium on 
indigenous traditions, value system and cultures i.e. ensuring that development programmes reflect their own priorities and re-awakening positive attitudes. A cursory study of ASEAN reveals the depth of commitment all obstructs to viable economic development. Veen (2011) notes that one of the striking features of the development of ASEAN is the emphasis on rural development. It should be realized that about $70 \%$ of Nigerians 150 million populations are domiciled in the countryside.

For a calibrated development process that is result-oriented to succeed in the Nigerian milieu, the gap between policy formulation and implementation must be bridged. This hiatus has been largely responsible for the emasculation of the various National Development Plans and the truncation of the rolling plans including the fiasico of Vision 2010 under the Abacha. Other landable programmes such as the Operation Feed the Nation of the Obasanjo administration, the Green Revolution of Shehu Shagari, the National Economic Empowerment Development Strategy have suffered the same fate of inertia and colossal failure. Currently the Vision 2020 of the Dr. Goodluck Jonathan as President of Nigeria in which the country hopes to catch up with the industrialized nations of the world may leave much to be desired if there is no symbiosis between policy formulation and implementation.

Similarly, there should be a deliberate effort on the part of leadership to locate other routes to holistic development of society. In this regard Jimada (2011) posits that Nigeria is destabilized because leadership had ceded to pressure to open the economy and society to global economies and cites the example of Mahathir Mohammed, the former leader of Malaysia that pulled the Malaysian currency off the world market, made it unconvertible and pegged it low enough to favour exports and stabilized the economy by blocking, the export of foreign capital and raised tarriffs' leading to growth in investment, production and export instead of crashing as predicted by Eurocentric Western economists. In the same vein, he further observes that leaders of Singapore such as Lee Kuan Yew and Lula da Silva of Brazil, are challenging the received wisdom of global economics and are clearly more interested in providing alternative egalitarian, anti-poverty policies and regional co-operation.

Very significantly, the hydra-headed monster of endemic corruption must be dealt a lethal blow. Against this backdrop of the realities of historical materialism Abba, Idris and Hamisu (2011) submit that "hypocrisy and primitive accumulation of wealth most especially in a foreign capital dominated economic and political reform". The term hypocrisy is a euphemism for official corruption that has become the bane of the Nigerian society since political independence. What is worrisome is that government institutions like the Independent Corrupt Practices Commission, ICPC and the Economic and Financial Crimes Commission, EFCC are losing steam in the onslaught against graft. Our national leadership must not confront corruption with kid gloves and there should be no sacred cows. First and foremost, all convicted corrupt leaders should forfeit their assets at home and abroad. Both the ICPC and EFCC have beamed searchlight on many sensitive corruption cases and urgent steps should be taken to dispose of such case files with justice meted.

Recovered loots should be ploughed back into the economy. A situation where in news broadcasts, the citizenry are alerted of loot recovery running into billions of naira, with no visible utilization of same, is political chicory. These should be an enabling law to make the punishment for corruption stricter. A state where an individual is found guilty of looting more than N20billion naira and is made to pay a fine of less than N1 million is laughable.

There is the dire need for value re-orientation that will demystify the lure of primitive accumulation at the detriment of the fate of the large society. Patriotic fervor in the spirit of statesmanship is a sine quo non for national development. Ozohu- Suleiman (2011) stresses the need for ethical values among public servants vis-a-vis the due process mechanism. Ethical re-orientation and the unfettered application of the rule of law should go parri-passu. The judiciary should be manned by men and women of proven integrity who will dispense justice with fairness equity and transparent morality (Sorkaa 2003).

Identifies the role of accountability and transparency in the development question

\section{Conclusion}

The concept of historical materialism emphasizes the primacy of matter in the relation of production with critical consequences for the polity. An integral element of this model is primitive accumulation which translates to the rabid selfish enrichment of the privileged few for wielding the apparatus of governance. This paper identifies the quest for economic advancement since the 1914 amalgamation and submits that some centrifugal from such as ravage of colonialism, corruption, lack of visionary leadership, the incidence of abject poverty, military inter-alia have derailed the process. 
A critical aspect of this paper deals with the challenge of abandoning national development plans for other less pragmatic models such as the rolling plans and Structural Adjustment Programme (S.A.P) of the Babangida years. The national development plans were rippled by the following factors; large scale corruption in high places, inflation, nonevolution of coherent polices designed to give the plan the direction it required, over invoicing, over-evaluation of contracts and indiscipline. Umearokwu (2011).

Joseph Stalin of the USSR and Mao-Tse-tung of China under communism formulated and implemented a development plan with enviable degree of success but the reverse has been the norm in the Nigerian example as a result of policy sommersaults and official corruption.

As a panacea to the national development quagmire, this paper recommends amongst others, a comparative approach that will tap from the economic engineering of Association of South East Asian Nation (ASEAN) whose membership have programmed viable alternative routes to the development question.

In no uncertain terms,this work calls for the entrenchment of visionary leadership, the elimination of official corrupton cum the adaptation of value re-orientation and the practice of the rule of law, the hallmark of good governance as fundamental condition for national development

\section{References}

Abba, A.S, Idris, A.A and Hamisu, A.A. (2011) Political economy, Nigerian economic reform

Political economy, Nigerian economic reform and the role of hypocrisy (1999 - 2007), Review of Nigerian political economy

Adeyomo, A.M (2003) Development and underdevelopment in a comparative perspective,

Port Harcourt: Amethyst and Colleague Press.

Ake, C. (1981) A political economy of Africa Nigeria. Longman.

Aluko, Y.A (2009) Corruption in Nigeria: Concept and dimensions, In Enweremadu, D. U and Okafor, E.E (Eds.) Anti-corruption reforms in Nigeria since 1999: issues, challenges and the way forward, IFRA special Research Issues (3).

Arokoyu, S.B (2004) Sustainability and sustainable development, Arokoyu, S.B, Nwosu, O.S, Dienye, V.U and Ifeanacho, M. (Eds) Perspective on world issues and problems.

Axtrian, R. (2004) The state of the state: The model of the modern state and its contemporary transformation, International political science review 25 (3).

Collingwood, R. G. (1946) The idea of history, Linchon: Oxford University Press.

Egwemi (2012) The amalgamation of 1914 and the north-south divide in Nigeria: Some comments on contemporary manifestations, Mangut, J. and Wuam, T. (Eds) Colonialism and transition in Africa, Lapai: Ibrahim Badamas; Babangida University.

Ekekwe, E. (1984) The State and economic development in Nigeria In Ake. C. (Ed) The political economy of Nigeria, Lagos: Longman.

Elaigwu, J. I (2011) Topical issues in Nigeria's political development, Jos:

Institute of Governance and Social Research (IGSR), Aha Publishing House.

Essoh, P.A (2005) Historical materialism in Marx's political thought, African journal of economy and society 5 (2).

Jimade, L.S (2011) The Challenges of Nation Building and the Experience of Post-colonial Governance in Nigeria, Barkindo, B.M, Ifamose, F. and Akpan, P (eds.) Nigeria at fifty: issues and challenges in governance, $1960-2010$.

Muhammed, S. (2011) The military and governance in Nigeria: Prospects and challenges of democratic governance, Barkindo, B. M Ifamosa, F. and Akpan, P (Eds) Nigeria at fifty: issues and challenges in governance 1960 - 2010, Markudi: Aboki Publishers.

Obasanjo, O. (1987) Nzeogwu Ibadan: Spectrum Books Ltd.

Oyeshola, D.O.P (2008) Sustainable development, issues and challenges for Nigeria,

Ibadan: Daily Graphics Nigeria Ltd.

Oyovbaire, S. (2007) The crisis of governance in Nigeria, Communication Lecture, University of

Port Harcourt.

Ozohu - Suleiman,A (2011) Ethics in government transaction: A perspective on the regime of due Process in Nigeria, Review of Nigeria political economy1 (1).

Radda, S.I (2008) Fighting poverty through the millennium development goals: Problems and prospects for Nigeria, Iwara, A. U (Ed.) Nigeria and the millennium development goals, 7th Annual Conference proceedings Fulbright Alumni Association of Nigeria (FAAN).

Ralph, P.L, Lerner, R.E, Meacham, S. Alan, T.W, Hull, R.W and Burns, E.M (1997) World civilizations, their history and their culture, Vol.II' New York: W.W. Norton and Co.

Salawu, B., Muhammed, A.Y, Adekeye, D.S and Onimajesin, I.S, (2006) Neglecting development plans and its implications for democracy and development in Nigeria Vol.2 Economic and environmental issues, Lagos: Concept Publications.

Soludo,C.C (2012) Nigeria towards the creation of incentives and structures for good governance, Guest Lecturer at the 2012 annual conference of the faculty of arts, Nnamdi Azikiwe University, Awka Nigeria.

Sorkaa, A.P (2003) Development as ethics and accountability in governance: the way forward for Nigeria, Makurdi; Benue State University Inaugural lecture series No. 1

Toyo, E. (2011) The project Nigeria: the journey so far, Calabar: Clear Lines Publications. 
Ugo, N. (2010) Nigeria: possible lessons from the ASEAN development model, Eze, O.C (Ed.) Beyond 50 years of Nigerian's foreign policy, issues, challenges and prospects, Lagos: The Nigeria Institute of International Affairs.

Umearokwu, U. (2011) The history and evolution of development planning in Nigeria, Review of Nigerian political economy 1 (1).

Undiyaundeye, U.A (2011) Colonialism and nation- building problems in Nigeria. Mangut, J. and Wuam, T (Eds.) Colonialism and the transition to modernity in Africa, Lapai Ibrahim Badamasi Babangida University.

Veen, R.V.D (2011) Nigeria - 50 years on: development prospects, Barkindo, B.M, Ifamosef, and Akpen, P (Eds) Nigeria at fifty: issues and challenges in governance $1960-2010$.

Wikipedia, Historical Materialism http:/len. Wikipedia.org/wiki.

Yusuf, T.M (1996) The Nigerian economy: growth without development, Benin: The Benin Social Science Series for Africa. 